\title{
Literary Form, Philosophical Content: Historical Studies of Philo- sophical Genres
}

Jonathan Lavery and Louis Groarke, eds.

Madison, N.J.: Farleigh Dickinson University Press, 2010, 268 pp., ISBN: $9780838642603(\mathrm{hc}), \$ 64.50$

\section{RICK ANTHONY FURTAK}

The editors of this collection point out at the start of the Preface that remarkably little has been written about the variety of literary genres used in philosophical writing. One notable exception is the Introduction of Martha C. Nussbaum's Love's Knowledge: Essays on Philosophy and Literature, which remains the best short discussion of the topic, and which is required reading for many "Philosophy and Literature" courses. Like Nussbaum's book, Literary Form, Philosophical Content opens with a general treatment of the theme announced in its title, and then proceeds to give readings of specific literary and philosophical texts in each of its later chapters. A particular virtue of this collection, edited by Lavery and Groarke, is its emphasis on the way that different genres and styles of philosophical writing are shaped by differing pedagogic aims: for instance, Joseph Butler's sermons are geared toward the faithful who seek to clarify and deepen their beliefs, whereas a Platonic dialogue might be more interested in awakening a reader's reflective faculties than in persuading him or her to accept a certain view. In spite of the often acknowledged links between form and content (i.e., what you say is not independent of how you say it), it nonetheless remains common practice in teaching philosophy to abstract arguments from the form in which they were written. The editors achieve their admirable goal of opposing this habit of disregard by showing the value of attending to the literary style of selected philosophical texts, assembling a series of chapters that address "the full range of genres available to philosophers in the tradition" (23).

Virtually all of the major Western philosophers, by anyone's count, are authors of one sort or another; and the rare exception, such as Socrates, is remembered as a philosopher mainly because he was admired and memorialized by a very good writer. Yet few people in the discipline of academic philosophy today seem to think of themselves as authors, even if they have written books, received royalties, and so forth. This is a fairly recent development, since it's clear that figures such as Hume and Schopenhauer regarded philosophical writing as a literary art—not only for authors of philosophical novels and dialogues, but even for those who were working in more straightforward prose genres such as the essay or the systematic treatise. Within the past century or so, both Russell and Bergson were awarded the Nobel Prize for Literature, primarily for the literary quality of their nonfiction philosophical works: so this is not an honor restricted to more obviously "literary" authors such as Camus and Sartre. If present-day academic philosophers tend to pay 
little attention to philosophical texts as literary works, this is a fairly recent prejudice. Still, prevailing biases can be difficult to alter-and the assumption that there is one evident way to write philosophy is all too easy to maintain with a dismissive shrug toward anyone who may suggest otherwise.

In response to those who hold such a dismissive attitude, Lavery and Groarke argue that it is misleading to consider as "standard" philosophical style the mode of writing found in most contemporary academic articles, as if this were characteristic of all works in the philosophical canon. Literary Form, Philosophical Content demonstrates that a vast assortment of styles and genres have been employed by philosophers-lecture, novel, essay, treatise, dialogue, commentary, biography, and meditation, among others. Even Plato's works vary in form, from the speeches of the Apology and the Symposium to the method of question-and-answer, or critical exchange, which prevails elsewhere. The sheer array of styles found in the philosophical tradition, encompassing almost anything that qualifies as "writing," affords plenty of material for the contributors to this volume. Glen Koehn shows how Sextus Empiricus uses a style that fits the therapeutic goals of ancient Skepticism, pairing every argument with a counterargument to help his reader arrive at the conclusion that it is best to suspend judgment. And Kevin Corrigan, in one of the best chapters in the volume, evaluates the reasons for using prayer as a spiritual exercise and a philosophical method: for instance, in Anselm's famous proof for God's existence, God himself is addressed in the second person, implying that the philosopher is engaged in a sacred practice and submitting his own rational arguments to the authority of a more perfect being, whose existence is affirmed even as it is being proven. As Groarke shows in his own chapter, Nietzsche's Birth of Tragedy deploys an "anguished, overstated" voice against the excessively complacent, optimistic, and measured discourse of theoretical, rationalistic philosophy (160). In the ancient quarrel, he takes the side of the poet-philosopher against the cold sobriety of "scientific" reason.

Berel Lang investigates the ethical issues that are bound up with the style adopted by a philosopher, contrasting A. J. Ayer's philosophical prose, in which the author poses as an "authority" whose answers the reader is bound to accept, with that of William James, in which the reader is addressed as a "friend" and fellow questioner (222-27). Additional chapters on more recent philosophers consider the distinctive stylistic and rhetorical strategies of authors ranging from J. L. Austin to Michel Foucault. Aristotle and Aquinas, like Plato and Machiavelli, receive careful consideration, as do less obvious figures such as Aesop and Bernard Mandeville. One of the few shortcomings of this volume is that it admittedly pays scant attention to some of the most inventive and versatile literary artists in the philosophical tradition-Kierkegaard, for instance, is mentioned only briefly early in the opening pages, as a major philosopher with an impressive stylistic range. It seems odd that he receives this acclaim by the editors and then is never mentioned again in 
any of the subsequent chapters. However, the collection makes no claim to be comprehensive. Rather, it presents itself as a set of studies, united by a common focus on literary style or genre as a key to interpreting philosophical works. While it may bear the traces of having grown out of a conference at which the topics covered were determined by the idiosyncratic interests of those who happened to be participating, it offers examples of how a literary approach to philosophical texts can enhance our appreciation of those texts, whether in or out of the classroom. It should be readable for advanced undergraduates, and will be of interest to all readers who are drawn to contemplate the shared terrain between philosophy and literature.

Rick Anthony Furtak, Department of Philosophy, Colorado College, Colorado Springs CO 80903; rfurtak@coloradocollege.edu

\section{From Warism to Pacifism, 2nd edition}

Duane L. Cady

Philadelphia: Temple University Press, 2010, 168 pp. ISBN: 9781439903124 (pbk.), $\$ 24.95$

\section{BARRY GAN}

The second edition of Duane Cady's From Warism to Pacifism is as refreshing as the 1989 first edition. Refusing to accept the dichotomies that generate needless strife and animosity between people, Cady's book models the positive peace and commitment to nonviolence that it urges upon us all. It would serve as a useful core text for courses on the culture of war, pacifism and the history of pacifism, peace studies, and positive peace, in part because it suggests many different avenues one can pursue with these topics, in part because its form reflects its content. Twenty years later, after the hopes that surrounded the end of the Cold War and after the despair that has enveloped so many following two wars in the Middle East and the events of September 11,2001 , the book remains vibrant and relevant, even without the useful rearrangements and additions to this new edition.

Cady's book is also well organized. The second edition moves the afterward of the first edition to the beginning of the book, as an introduction. The introduction summarizes the history of pacifism as an idea, from Thucydides and Aristophanes to John Dewey and William James. The book continues by discussing the U.S.'s dominant and pervasive cultural orientation toward war and preparation for war. Before contrasting warism with pacifism, Cady analyzes the just war tradition and the continuum that it comprises. Then follows an enlightening discussion of means and ends, crucial to the distinction that Cady makes between warism and pacifism, even as he sees an overlap between them. Before turning toward the culminating points of the book, Cady introduces pacifism itself and discusses many varieties of pacifism, varieties 